\title{
The Impact Of Oil And Gas Production On The Nigerian Economy: A Rural Sector Econometric Model
}

\author{
Matthew Nga Uwakonye, (Email: uwakonye@yahoo.com), Grambling State University \\ Gbolahan Solomon Osho, (Email: oshogs@tsu.edu), Texas Southern University \\ Hyacinth Anucha, (Email: h_anucha@yahoo.com), Sojourner - Douglass College
}

\begin{abstract}
The oil economy of Nigeria is very important to the country, but the people of Nigeria still suffer from a corrupt government. Despite the revenues being brought in from oil exports, the Nigerian government still holds a large unemployment rate and a high poverty rate. This paper shows the amount of oil being produced per day, as well as, the process by which the oil is brought to the market. This paper also shows the labor to GDP ratio, the major exports, and the major imports of Nigeria. Finally, an understanding of the ethnic struggle within Nigeria is looked at, as well as, the illegal oil racketeering that is costing the Nigerian governments billions of dollars. Until the people of Nigeria can take control of its government and rid themselves of the crushing militias that controls the politics in Nigeria, the people are doomed to suffer.
\end{abstract}

\section{INTRODUCTION}

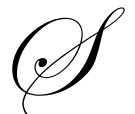

ince the discovery of Nigerian oil in 1956 and its rise to the tenth largest oil-producing nation in the world, Nigeria has remained a country of political unrest, social disorder and economic instability whose national ills continue to be linked to its greatest but most corruptive factor, 'the dark nectar' of Africa. Since its transition to civilian rule, political attempts to stabilize friction among Nigerians and multinational oil companies have been made to ensure production and cut export losses. However, fighting between rival ethnic groups continues to slow production and provides an unreliable producer that has been offset by the recent discovery of offshore oil deposits, which is expected to increase GDP.

As a major oil-producing nation, the fluctuation of Nigeria oil production, prices and inflation can cause problems for regions such as the United States, Western Europe, and Asia, who have taken refuge in Nigerian oil due to the current tension in the Middle East. With such large potential for success, Nigeria remains one of the poorest countries in the world with much of its profits going to the multinational oil companies that populate the country including Royal/Dutch Shell, ChevronTexaco, ExxonMobile, TotalfiaElf, Agip and PanOcean Oil with the NNPC receiving only $57 \%$ of profits. While multinational contractors receive almost half of Nigerian oil profits, local Nigerian contractors receive far less due to their relatively low employment in the oil industry. Not only are local contractors omitted from the large sums received by the multinational oil companies, but also most of Nigeria's populations are unemployed with a very small percentage benefiting from its native breadwinner.

With the cultivation of massive amounts of money and oil, Nigeria has also reaped havoc upon its environment risking local communities, crops and ecosystems, most of which are given little thought when oil deposits are present. Nigeria's plethora of oil can bring it to great heights, expanding its wealth to an impoverished country bringing education, health, political and social order to its people. However, until improvements are made within the newly established government, and relations between the Nigerian people and inhabitant oil companies are properly instituted, Nigeria will continue to cultivate a restless and poorly maintained country. The objective of this paper is to show the impact of oil to the Nigeria economy. 


\section{THE IMPACT OF OIL PRODUCTION ON THE NIGERIAN ECONOMY}

As the $10^{\text {th }}$ largest oil producer in the world and the third largest in Africa, Nigeria has an economy that is very dependent upon its oil sector. It accounts for $95 \%$ of Nigeria's foreign exchange earnings, and they have oil reserves estimated between 24 billion and 31.5 billion. They produce 90 million tons per year. And with an economy based so explicitly around one product, it is almost impossible for it not to affect everything about Nigeria's structure and culture. The civil unrest that has plagued the country since the end of the $18^{\text {th }}$ century was only fueled by demand for control of this new market. In the late 1950's, Nigeria began to drill for oil and in 1970 during the oil boom, unrest escalated to an all out civil war. Because of corruption and misuse of power, the oil market has produced very little social and structural development in Nigeria. The general Nigerian population fails to see the investment of the oil revenue back into their lives. Nearly $95 \%$ of oil produced in Nigeria is produced through the joint venture there, Shell being the largest and producing nearly $50 \%$. Nigeria sees about $60 \%$ of what they produced. Nigerian GDP fluctuates with the booms of oil and overspending of the government and is not always in hand with the amount of oil being produced. Employment and literacy rates have risen slowly with the coming of the oil market but energy output has been severely damaged by drilling and oil spills.

Nigeria covers an area of $923,768 \mathrm{sq} \mathrm{km}(356,669 \mathrm{sq} \mathrm{mi})$ and is by far the most populated of Africa's countries. Nigeria has a tropical climate and about two-thirds of Nigeria lies in the watershed of the Niger River, which empties into the Atlantic at the Niger Delta. Petroleum and natural gas, the source of most of Nigeria's export earnings, are concentrated in large amounts in the Niger Delta and just offshore. Smaller deposits are scattered elsewhere in the coastal region.

There are two main oil markets in Nigeria: an upstream and a downstream. The upstream oil industry, based in the fertile Niger River Delta, is the most important economic sector in Nigeria's economy producing over $90 \%$ of its total exports. Oil in the upstream market is produced from 5 of Nigeria's 7 sedimentary basins: the Niger Delta, Anambra, Benue Trough, Chad, and Benin. About $80 \%$ of oil-producing wells are drilled in the upstream sector.

The major foreign stakeholder in this region is Shell. But as Nigeria's economic backbone, the upstream sector also proves central to the ongoing civil unrest in the country. Nigeria's downstream economy has four refineries with a capacity of $445,000 \mathrm{bbl} / \mathrm{day}$. But they often only operate at $40 \%$ of full capacity because of fire, corruption, poor management and incapacitation. Cross-border smuggling is an ongoing problem and there are frequent reports of large scale corruption in the distribution and marketing chain. The government through the NNPC has had an all encompassing control over the industry through its shareholding in all the companies involved and in the setting of wholesale and retail prices. This has produced shortages of refined product that Nigeria needs to meet domestic demands and their own quotas (1.89 million bbl/d). Deregulation of the downstream oil area is a stated aim of the government, but this is likely to depend on the still heavily sponsored prices allowed to rise to international levels.

Until 1960, Britain controlled Nigeria and their natural resource mines and government participation in the oil industry was limited to the regulation and administration of fiscal policies. In 1960, Nigeria declared independence, but the Nigerian government was not ready for independence. In 1966, the cultural and social tensions between the north and the south erupted into a series of massacres, and a military coup that installed the first series of military governments. This was followed by a three year civil war that left 1,000,000 dead. After the civil war Nigeria joined OPEC. In line with their resolutions, the Nigerian National Oil Corporation was established which in 1977 became the Nigerian National Petroleum Corporation. It continues to dominate all areas of the oil industry, both up and downstream. Nigeria entered a period of prosperity and quickly rising oil pushed the Nigerian government into a reckless spending spree. Corruption became rampant and when the world recession and oil bust of the 1980's hit, inflation soared; there was large scale unemployment, massive debt and widespread corruption.

In 1993 a new leader, General Abacha, became the leader. He ruled as a despot and failed to bring about the democracy he promised. He was censured by human rights group for his execution of the play-write Ken Saro-Wiwa and civil unrest again broke out, hindering oil production and still keeping the general population from seeing any sort of return from it. When Abacha died in 1998, he was replaced by General Abubakar who promised a return to civilian 
rule. He kept his promise and in 1999, Olusegun Obasanjo, a former military leader and political prisoner until 1998, was elected president. In April of 2000, the Nigerian government set up a new committee on oil and gas reform to deal with the deregulation and privatization of NNPC.

Many Nigerians regard oil as a gift from God believe it is their right to enjoy it at cheap prices, a belief which begins to sum up the risks of investing in Nigeria. The civil unrest from the oil market in Nigeria is based around the inequitable sharing of the countries oil revenues among its population. The Nigerians feel as though they are not benefiting from their natural resources, creating the civil unrest that often makes it dangerous or risky to invest in Nigeria; 700 deaths and shut off terminals and flow stations are just some of the results. Corruption within the industry and the government creates a very tough situation when the people lack equitable sharing and the revenue from the oil market is not being pumped back into the economy or the right places in the society.

The government has failed to stop this in the past too, and environmental responsibilities of the oil companies are not often addressed. Nigerians border disputes also exacerbate this risky situation. While the Nigerians feel it is their land and their oil, Cameroon and Guinea feel that it is theirs. Negotiations between the two countries have met little if any success. Apart from those social concerns there is also an inability for the NNPC to meet funding obligations to the JVs. The government is seeking to diversify funding for the industry and alternative funding schemes.

\section{Nigeria GDP 1972-2004}

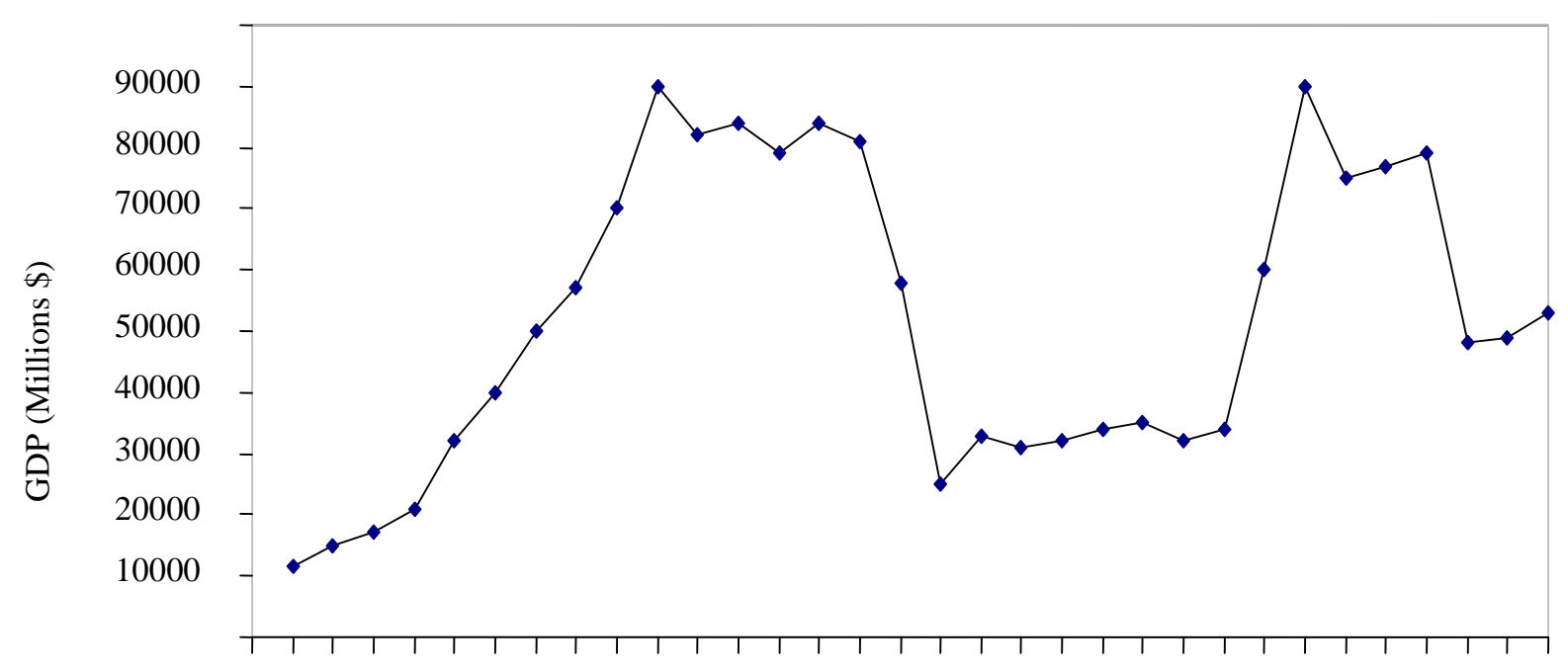

197219741976197819801982198419861988199019921994199619982000

Year

The GDP in millions of U.S. dollars is illustrated over a 30 year period by the purple line on the above graph. In 1970, Nigeria had just become a member of OPEC and their annual GDP began being recorded. As they entered OPEC, they began a harnessing of their natural resources prevalence. Their GDP was on a very, steady and fast rise throughout the 1970s at an average of almost $\$ 5$ billion per year. But after a peak in 1981, the global recession hit and their period of prosperity caused by their oil boom began a decline. Illustrated in the graph, the decline begins slowly at first but in 1987 drops sharply and stays very low for a period of 8 years.

Their oil economy rose sharply again in 1996, peaking due to exploration and success with new areas of high risk drilling in deep and ultra deep areas. Their prosperity lasted only a few years and fell again in 1999 with the election of their new president. With the change from a military government to a civilian run government, the oil 
multinationals were hesitant about their investments because of the extreme risk in the new base of the government, but it began a rise again in 2000, growing at a very similar rate to that of the rise in 1970 . If the government wishes to contain a steady rise or hold a high constant GDP it will be necessary for them to anticipate recessions and rule out reckless spending in times of prosperity.

\section{THE MODEL CONSIDERATION}

The rural sector's population is $N I$ and $A$ is the total energy land area which is owned within the rural sector. Intrasectoral distribution is ignored, and a $=A / N^{1}$ is the land area per worker. The term $L^{1}$ denotes the hours worked by each worker. The production technology exhibits constant returns to scale, and $X \equiv X\left(A / N^{1}, L^{1} 1\right) \equiv X\left(a, L^{1}\right)$ is the output per worker. A rural worker's consumption of the rural and the urban good is denoted by $\left(x^{1}, y^{1}\right)$. The surplus of the rural good per worker, Q, is given by

$$
\mathrm{Q}=\mathrm{X}-\mathrm{x}^{1}
$$

The relative price of the rural good in terms of the urban good is denoted by $p$. A rural worker's budget constraint becomes

$$
p \mathrm{Q}=\mathrm{y}^{1}
$$

A rural worker's utility is represented by $U^{1}=U\left(x^{1}, y^{1}, L^{1}\right)$. The indirect utility is obtained from

$$
V^{1}\left(p, N^{1}\right)=\max _{x^{1}, y^{1}, L^{1}}\left(\mathrm{x}^{1}, \mathrm{y}^{1}, \mathrm{~L}^{1}\right)+\lambda^{1}\left[p X\left(A / N^{1}, L^{1}\right)-p x^{1}-\mathrm{y}^{1}\right]
$$

From the envelop theorem

$$
\partial V^{1} / \partial p=\lambda^{1} Q>0
$$

and

$$
\partial V^{1} / \partial N^{1}=-\lambda^{1} p X_{a} a / N^{1}<0
$$

where $X_{a}=\partial X / \partial a$, and $\lambda^{i}$ is the (positive) marginal utility of income in sector $i$. It is evident that the rural surplus is a function of the relative price and the rural population, that is, $Q \equiv Q\left(p, N^{1}\right)$. It is also worth keeping in mind that, in our notation, an increase in the size of price scissors, that is, in an increase in the relative price of the urban good, corresponds to decrease $\mathrm{p}$.

The urban population is $N^{2}$, and an urban worker supplies $L^{2}$ hours of work which are fixed by the government, based on technological consideration. The urban consumption of the rural and the urban good is denoted by $\left(x^{2}, y^{2}\right)$, and $w$ is the wage per hour, in terms of the industrial good. The budget constraint of an urban worker is given by

$$
p x^{2}+y^{2}=w L^{2} .
$$

Denoting the urban individual's utility function by $U^{2}=U\left(x^{2}, y^{2}, L^{2}\right)$, the indirect utility is obtained form

$$
V^{2}(p, w)=\max _{x^{2}, y^{2}} U\left(x^{2}, y^{2}, L^{2}\right)+\lambda^{2}\left[w L^{2}-p x^{2}-y^{2}\right]
$$


The envelope theorem yields

$$
\partial V^{2} / \partial w=\lambda^{2} L^{2}>0
$$

and

$$
\partial V^{2} / \partial p=-\lambda^{2} x^{2}<0
$$

Naturally, the urban consumption is a function of the relative price and the urban wage, that is, $x^{2} \equiv x^{2}(p, w)$. The consumption goods are assumed to be normal. The output of an urban worker is denoted by $Y \equiv Y\left(k, L^{2}\right)$, where $k=K / N^{2}$ is capital stock per urban worker, and $\mathrm{K}$ is the total urban capital stock.

The economy under consideration is a closed economy. The sectoral populations are fixed. The total population is $\mathrm{N}$, and

$$
N=N^{1}+N^{2}
$$

The two basic constraints in the economy are the quantity balances of the urban and rural goods, respectively. Defining $I$ as the state's surplus of the urban good, we have

$$
I=N^{2} Y-N^{2} y^{2}-N^{1} y^{1} ; I=\dot{K} .
$$

That is, the urban output is used either for consumption or for investment. Similarly, the balance between the supply and demand of the rural good requires

$$
N^{1} Q\left(p, N^{1}\right)=N^{2} x^{2}(p, w) .
$$

\section{PREOBRAZHENSKY'S FIRST PROPOSITION}

Preobrazhensky's most important claim was that the state can increase accumulation by moving the terms of trade against presents, that is, by increasing the size of scissors. For ease of reference, we call this Preobrazhensky's first proposition. Naturally, this proposition is quite basic, because it asserts the feasibility of using the terms of trade as an instrument for society's accumulation.

Recall that moving the terms of trade against peasants means a decrease in;. The above proposition thus says: $d I / d p<0$. To examine the conditions under which this proposition holds, we obtain an alternative expression for the state's surplus. Substitution of (2), (5), and (10) in (9) yields

$$
I=N^{2}\left(Y-w L^{2}\right)
$$

The state's surplus is therefore the difference between the urban output and the wage payment to the urban workers, and the surplus does not directly depend on the terms of trade, $p$.

A change in $p$, however, requires a change in the urban wage $w$ if the demand and supply balance of the rural good, (10), is to be preserved. To obtain the relation between $p$ and $w$, we first defined some notation. Let $m=$ $w L^{2}$ be the income of an urban worker,

$$
\begin{aligned}
& \varepsilon_{Q p}^{1}=\partial \ln \mathrm{Q} / \partial \ln p, \\
& \varepsilon_{x p}^{2}=-\partial \ln x^{2} / \partial \ln p
\end{aligned}
$$


and

$$
\varepsilon_{x m}^{2}=\partial \ln x / \partial \ln m
$$

be, respectively, the price elasticity of the rural surplus, the price elasticity of the urban consumption of the rural good, and the income elasticity of the urban consumption of the rural good. Also, define $\varepsilon_{w p}$ as the percent change in the urban wage which must accompany a percent increase in $p$. That is,

$$
\varepsilon_{w p}=\partial \ln w / \partial \ln p
$$

Next, differentiation of (10), and the use of the above definitions yields

$$
\varepsilon_{w p}=\left(\varepsilon_{Q p}^{1}+\varepsilon_{x p}^{2}\right) / \varepsilon_{x m}^{2}
$$

The change in the state's surplus due to a change in the terms of trade is then obtained from (11) and (14) as

$$
d I / d p=-N^{2} w L^{2}\left(\varepsilon_{q p}^{1}+\varepsilon_{x p}^{2}\right) / p \varepsilon_{x m}^{2} .
$$

In the above expression, the sign of the rural surplus response, $\varepsilon_{Q p}^{1}$, is not predictable theoretically because this response is a composite of the production response, the consumption response, and the labor supply response. Based on this evidence, we maintain throughout the paper that

$$
\varepsilon_{Q p}^{1}>0
$$

Now, looking at the right side of (15), $\varepsilon_{x p}^{2} a n d \varepsilon_{x m}^{2}$ are positive because consumption goods are normal. Using (16), therefore $d I / d p<0$. (In fact, the same result will hold even if $\varepsilon_{Q p}^{1}$ is negative within some range.)

This proposition can be expressed in our notation as: $d V^{2} d p \leq 0$. From the earlier analysis, it is clear that there are two effects of changing the terms of trade on an urban worker: a direct price effect, and an indirect effect due to the induced change in the urban wage. The total effect is expressed as

$$
\frac{d V^{2}}{d p}=\frac{\partial V^{2}}{\partial p}+\frac{\partial V^{2}}{\partial w} \frac{d w}{d p}
$$

Substitution of (7) in the above yields

$$
\frac{d V^{2}}{d p}=\lambda^{2}\left[-x^{2}+\frac{w L^{2}}{p} \varepsilon_{w p}\right]
$$

We define $\alpha^{2}=p x^{2} / w L^{2}$ as the urban budget share of the rural good, and $\varepsilon_{x p}^{2 u}=-\left(p / x^{2}\right)\left(\partial x^{2} / \partial p\right) \overline{v^{2}}$ as the price elasticity of the compensated demand for the rural good in the urban sector. Using this definition, the Slutsky expression can be as

$$
\varepsilon_{x p}^{2}=\varepsilon_{x p}^{2 u}+\alpha_{x}^{2} \varepsilon_{x m}^{2} .
$$


Substitution of (14), and (19), in (18) gives

$$
\frac{d V^{2}}{d p}=\frac{\lambda^{2} x^{2}}{\alpha_{x}^{2}} \frac{\left(\varepsilon_{Q p}^{1}+\varepsilon_{x p}^{2 u}\right)}{\varepsilon_{x m}^{2}} .
$$

In the above expression, $\varepsilon_{x p}^{2 u} \geq 0$ form the standard Slutsky property of compensated demand. It follows from (16) and (20) that $\mathrm{d} V^{2} / d p>0$ Also note that a higher $\varepsilon_{Q p}^{1}$ corresponds to a higher $d V^{2} / d p$.

The aim of a policy reform analysis is to identify rules for an improvement in society's overall welfare. Naturally any such rule is more useful if less information is required to apply it. The results in this section are particularly significant from this paint of view because, as we shall see, their application requires quite minimal information.

The first step in the analysis of reform is to define the aggregate social welfare. For this, we use an additive Bergson-Samuelson social welfare function, $\psi$, to aggregate over individual utilities.

$$
\psi=N^{1} W\left(V^{1}\right)+N^{2} W\left(V^{2}\right)
$$

where $\mathrm{W}$ is concave and increasing in $\mathrm{V}$. If $\delta$ is the social value of the marginal investment, then the current value of the aggregate social welfare, $\mathrm{H}$, is given by

$$
H=\psi+\delta I
$$

Substituting (11) in (22)

$$
\begin{aligned}
& H=N^{1} W\left(V^{1}\left(p, N^{1}\right)\right) \\
& +N^{2} W\left(V^{2}(p, w)\right)+\delta N^{2}\left[Y-w L^{2}\right]
\end{aligned}
$$

The above expression is now perturbed with respect to $p$, while ensuring a corresponding perturbation in the urban wage to preserve the identity (10). Using (4) and (7), we obtain

$$
\begin{aligned}
& \frac{d H}{d p}=\frac{\partial H}{d p}+\frac{\partial H}{\partial w} \frac{d w}{d p} \\
& =N^{1} \beta^{1} Q+N^{2} \beta^{2}\left[-x^{2}+\frac{w L^{2}}{p} \varepsilon_{w p}\right]-\delta N^{2} w L^{2} \varepsilon_{w p} / p,
\end{aligned}
$$

where $\beta^{i}=\lambda^{i} \partial W / \partial V^{i}$ is the social value of a marginal increase in the income of a worker in sector $i$. The three terms on the right-hand side of (24) represent, respectively, the welfare gain to the rural sector, the welfare gain to the urban sector, and the loss of investment due to an increase in the relative price of the rural good. Naturally, these gains and losses are weighted by their respective social weights.

Using (10), and the definition of the budget share, $\alpha_{x}^{2}(24)$ can be expressed as

$$
d H / d p=N^{2} x^{2}\left[\left(\beta^{1}-\delta\right)+\left(\beta^{2}-\delta\right)\left(\varepsilon_{w p} / \alpha_{x}^{2}-1\right]\right.
$$


The expression (25) can now be used to trade, that is, the sufficient conditions which will guarantee that a specific change in the relative price will increase the social welfare. Rewriting (25), we obtain

$$
d H / d p=N^{2} x^{2}\left[\left(\beta^{1}-\delta\right)+\left(\beta^{2}-\delta\right)\left(\varepsilon_{w p} / \alpha_{x}^{2}-1\right]\right.
$$

Next note from (19) that $\varepsilon_{x p}^{2} / \alpha_{x}^{2} \varepsilon_{x m}^{2} \geq 1$, because $\varepsilon_{x p}^{2 u} \geq 0$. Further, as $\varepsilon_{Q p}^{1}>0$, it follows from (14) that

$$
\varepsilon_{w p} / \alpha_{x}^{2}>1
$$

Substitution of the above in (26) yields the following two rules for reforms:

$$
d H / d p<0, \text { if } \beta^{1} \leq \delta \text { and } \beta^{2} \leq \delta
$$

(with at least one strict inequality).

$$
d H / d p>0, \text { if } \beta^{2} \geq \delta \text { and } \beta^{2} \geq \delta
$$

(with at least one strict inequality).

From (28) and (29), we find that: moving the terms of trade against (in favor of) peasants is described if the social weight on investment is greater (smaller) than the social weights on rural and urban income. Note that this rule holds no matter which one of the two social weights on income is larger. The reason for this is quite simple. If the social valuation of a dollar of investment exceed the losses due to decreased consumption, regardless of which one of the tow sets of workers is worse off.

A final paint needs to be emphasized here. The above analysis clearly shows that, over a range of social weights, the decision to widen or to narrow the price scissors is independent of the comparison between rural and urban welfare. Instead, this decision depends on the intertemporal comparison between consumption and investment.

We are already in a position to recognize some features of the optimal price structure. Assuming that a unique interior maximum exists for our maximization problem, we should have $d H / d p=0$ at the optimum. The necessary conditions for this characteristic of the optimum can be extracted from (28) and (29). We find that the optimal price structure must satisfy. ${ }^{14}$

$$
\beta^{1}>\delta>\beta^{2}, o r \beta^{2}>\delta>\beta^{1}
$$

In other words, if the social weight on investment does not lie between the social weights on the rural and the urban income, then the regime is not optimal, and it can be improved through price policy. This result needs to be contrasted with a view often held in the literature on project evaluation that the social weight on investment should be higher than the (undifferentiated) social weight on consumption (Yotopoulos and Jeffery Nugent, 1976, p. 385, for example). The view is incorrect if the terms of trade can be uses as an instrument of policy.

To obtain the optimal tax formula, the following Lagrangian is defined by explicitly incorporating the rural good constraint, (10), into the maximand

(Available from the authors.)

where $\psi$ is given by (21), and $p$ and $w$ are the control variables. ${ }^{15}$ The first-order conditions with respect to $p$ and $w$, after some manipulation ${ }^{16}$, can be written as 


$$
\begin{aligned}
& s=\left(\beta^{1}-\beta^{2}\right) / \delta\left(\varepsilon_{Q p}^{1}+\varepsilon_{x p}^{2}\right), \\
& s=\left(\delta-\beta^{2}\right) / \delta \alpha_{x}^{2} \varepsilon_{x m}^{2}
\end{aligned}
$$

Equations (32) and (33) are alternative expressions for the optimal subsidy rate, and these can be easily interpreted. Note from (32) that $\mathrm{s}$ is positive or negative depending on whether $\beta^{1}$ is greater than or smaller than $\beta^{2}$. A higher $\beta$, on the other hand, corresponds to a lower level of utility. The expression (32), therefore, clearly demarcates the location of the optimal tax (or subsidy) between the two sectors: workers who are better off should be taxed, while the workers who are worse off should be subsidized. This result is independent of the behavioral responses in the economy, of the social valuation of investment, and of whether the peasants or the industrial workers are better off. Note, however, that the magnitude of subsidy does depend on the social weight on investment.

$$
p x^{2}\left(\beta^{1}-\beta^{2}\right)=w L^{2}\left(\delta-\beta^{2}\right) \varepsilon_{w p}
$$

The above expression equates the net social gain from a price increase to the net social loss due to the price-induced wage increase. Rearranging the terms in (34), we obtain a remarkably simple rule to characterize the optimum.

$$
\frac{\left(\delta-\beta^{2}\right) \varepsilon_{w p}}{\left(\beta^{1}-\beta^{2}\right)}=\alpha_{x}^{2} \equiv \text { budget share }
$$

In the above analysis we have employed the terms of trade as the instrument of control. This we have done to keep the analysis within the context of the scissors problem. There are several alternative ways, however, in which the present problem can be characterized.

First, consider the control of the nominal price of the urban good or the nominal urban wage, because it is through these variables that a terms-of-trade policy can actually be implemented. It can be verified that an increase in the nominal price of the urban good corresponds to a movement in the terms of trade against the rural sector, and that an increase in the nominal urban wage corresponds to a movement in the terms of trade in favor of the rural sector. Either one of these two nominal variables can therefore be used as the instrument of control, without affecting the results.

Second, the economic content of the analysis remains unchanged if either the level of investment, I, or the rural surplus, $Q$, is used as the independent policy instrument. In these cases the analysis will correspond to what is sometimes called the "investment problem," and the "marketed surplus" problem.

Third, our conclusions regarding the terms of trade remain essentially unaltered if the "modern" capital good produced in the urban sector can be productively employed in the rural sector, and if the government exercises the choice over the intersectoral location of investment. As a simple example, consider the case in which there is positive investment in both sector and the rent on the rural capital accrues to the rural sector. Then it can be verified that pricing rules (32)-(35) continue to characterize the optimum. Similarly our qualitative results on the terms of trade will not change if a time-dependent process of technical progress in production I incorporated in the model.

Finally, we can reinterpret our analysis in a decentralized economic setting. To see this first imagine that the government instructs its public sector managers to maximize profits based on the nominal prices they face, but introduces either a commodity tax on the urban good or a wage tax. Naturally, then, the government can control the terms of trade at any level that it desires. In particular, the optimum which we analyzed earlier is implementable in this manner. Next, assume that the industrial production is privately owned, but that the government imposes a 100 
percent profit tax, and that it also imposes one of the two taxes mentioned above. It follows that the desired public policy can be implemented through a private market equilibrium.

Table 1: Empirical Analysis Of Oil Boom And Tax Yield 1970-1990

\begin{tabular}{|l|l|l|l|l|l|l|l|l|l|}
\hline Equation & Constant & $\begin{array}{c}\text { Elasticity } \\
\text { co-efficient }\end{array}$ & $\begin{array}{c}\text { Elasticity } \\
\text { co-efficient } \\
\text { lagged } \\
\text { values }\end{array}$ & \multicolumn{1}{|c|}{ Slope } & Shift & F- & $\mathbf{R}^{\mathbf{2}}$ & DW & SER \\
statistics & & & & \\
\hline 1 & -1.104 & 0.643 & 0.265 & 0.00000006 & 0.730 & 457.05 & 0.984 & 1.817 & 0.225 \\
\hline 2 & $(1.516)$ & $(3.992)$ & 1.0607 & $(0.631)$ & $(2.940)$ & & & & \\
\hline & 0.8649 & 0.223 & 0.565 & 0.0000061 & 0.173 & 302.29 & 0.977 & 1.753 & 0.204 \\
\hline 3 & $(0.967)$ & $(1.522)$ & $(3.062)$ & $(3.362)$ & $(1.040)$ & & & & \\
\hline & 0.254 & 0.297 & 0.466 & 0.0000018 & 0.209 & 162.27 & 0.957 & 1.987 & 0.258 \\
\hline 4 & $(0.326)$ & $(2.166)$ & $(2.793)$ & $(1.674)$ & $(1.260)$ & & & & \\
\hline & -0.163 & 0.738 & 0.111 & 0.0000092 & -0.145 & 501.18 & 0.986 & 1.437 & 0.149 \\
\hline 5 & $(0.355)$ & $(7.008)$ & $(1.097)$ & $(1.462)$ & $(0.989)$ & & & & \\
\hline & -0.777 & $(1.407)$ & 0.846 & 0.0000019 & -0.216 & 243.06 & 0.971 & 1.99 & 0.245 \\
\hline 6 & $(0.806)$ & 0.192 & $(8.588)$ & $(0.178)$ & $(1.111)$ & & & & \\
\hline & -0.787 & $(1.364)$ & 0.841 & 0.0000062 & -0.188 & 240.44 & 0.971 & 1.947 & 0.246 \\
\hline 7 & $(0.838)$ & -0.076 & $(8.313)$ & $(0.301)$ & $(1.031)$ & & & & \\
\hline & 1.172 & $(0.144)$ & 1.092 & 0.0000015 & -0.905 & 203.37 & 0.965 & 1.423 & 0.777 \\
\hline 8 & $(0.268)$ & 0.684 & $(6.099)$ & $(0.373)$ & $(1.176)$ & & & & \\
\hline & -2.473 & $(3.578)$ & 0.719 & 40.000013 & -1.084 & 310.16 & 0.977 & 1.256 & 0.632 \\
\hline 9 & $(2.861)$ & 0.245 & $(5.836)$ & $(2.054)$ & $(1.739)$ & & & & \\
\hline & -1.084 & $(1.441)$ & 0.736 & 0.0000052 & 0.219 & 420.22 & 0.983 & 2.159 & 0.241 \\
\hline 10 & $(0.991)$ & 0.205 & $(5.384)$ & $(0.534)$ & $(1.027)$ & & & & \\
\hline & -0.817 & 0.205 & 0.761 & 0.0000152 & 0.246 & 395.29 & 0.982 & 2.136 & 0.248 \\
\hline
\end{tabular}

Table 2 reports interesting results regarding the effects of SAP on the Productivity of the revenue sources. Forexample the elasticity index for GTR was very significant for both current and lagged values of GPA. Further analysis shows that this finding was attributable to two main revenue sources, IMD and PPT, in which both the current and lagged values of GDP were significant. Similar findings were reported for PPT and TOS. This is a rather puzzling findings, which may be attributable to massive leakages and the magnitude of revenue involved. However, the determination of the actual causes of this finding awaits further research.

This suggestion is reinforced by the finding for IMD in relation to IMP where only the current value of GDP was found significant which is consistent with expectation given that import duties are assessed and payable immediately before the release of imported items. It also reflects a mopping-up of most of the laxity of the oil boom era in collection and timely remittance of import duty proceeds.

Contrary to expectation, SAP did not affect the behavior of the revenue sources. The only exception was NOR where both the intercept and the slope were positively and significantly affected. The findings suggest a renewed focus on enhanced efficiency in the administration of non-oil revenue sources during the SAP period. This was desirable reversal of the trend of the oil boom era when there was near total neglect of these other revenue sources. The investigation is explored within a vector autoregressive system. The results reveal that the energy sector exerts a significant influence on the Nigerian economy by acting as a prime mover. More importantly, Nigeria seems to find itself in a vicious circle, because of its inability to exercise control over the price of its main export and its imports. Thus, the strength and autonomy exhibited by Nigerians macroeconomic managers during the oil boom era appears to have been barren. 
Table 2: Structural Adjustment And Tax Yield In Nigeria (1970 - 1990)

\begin{tabular}{|c|c|c|c|c|c|c|c|c|c|}
\hline Equation & Constant & $\begin{array}{c}\text { Elasticity } \\
\text { co-efficient }\end{array}$ & $\begin{array}{c}\text { Elasticity } \\
\text { co-efficient } \\
\text { lagged } \\
\text { values }\end{array}$ & Slope & Shift & $\begin{array}{c}\text { F- } \\
\text { statistics }\end{array}$ & $\mathbf{R}^{2}$ & DW & SER \\
\hline \multirow[t]{2}{*}{1} & -1.767 & 0.509 & 0.2594 & 0.00000034 & -0.139 & 342.16 & 0.979 & 1.984 & 0.259 \\
\hline & $(2.243)$ & $(2.749)$ & $(4.101)$ & $(0.284)$ & $(0.554)$ & & & & \\
\hline \multirow[t]{2}{*}{2} & -0.365 & 0.219 & $0 / 759$ & 0.0000071 & -0.553 & 315.31 & 0.977 & 2.063 & 0.199 \\
\hline & $(0.847)$ & $(1.513)$ & $(4.779)$ & $(3.144)$ & (1.993) & & & & \\
\hline \multirow[t]{2}{*}{3} & -0.533 & 0.342 & 0.556 & 0.00000048 & 0.137 & 154.88 & 0.955 & 2.142 & 0.264 \\
\hline & $(1.127)$ & $(2.555)$ & $(3.393)$ & $(0.408)$ & $(0.536)$ & & & & \\
\hline \multirow[t]{2}{*}{4} & 0.074 & 0.706 & 0.103 & 0.0000051 & 0.184 & 569.54 & 0.987 & 1.752 & 0.240 \\
\hline & $(0.434)$ & $(9.322)$ & (1.079) & $(0.888)$ & $(1.317)$ & & & & \\
\hline \multirow[t]{2}{*}{5} & 0.302 & 0.121 & 0.858 & 0.000001 & -0.252 & 238.39 & 0.970 & 1.816 & 0.246 \\
\hline & $(0.513)$ & (1.44) & $(8.439)$ & $(1.070)$ & $(1.033)$ & & & & \\
\hline \multirow[t]{2}{*}{6} & -0.429 & 0.141 & 0.850 & 0.0000037 & -0.457 & 243.44 & 0.970 & 1.818 & 0.244 \\
\hline & $(0.661)$ & $(1.226)$ & $(8.305)$ & $(1.3015)$ & $(1.315)$ & & & & \\
\hline \multirow[t]{2}{*}{7} & 1.736 & -0.148 & 1.010 & 0.00000092 & 0.039 & 193.24 & 0.963 & 1.221 & 0.796 \\
\hline & $(0.4210$ & $(0.294)$ & $(6.734)$ & $0.245)$ & $(0.051)$ & & & & \\
\hline \multirow[t]{2}{*}{8} & -0.487 & 0.68 & 0.59 & -0.005 & -0.98 & 218.9 & 0.97 & 0.87 & 0.67 \\
\hline & (2.66) & $(3.27)$ & (5.06) & $(0.38)$ & $(0.82)$ & & & & \\
\hline \multirow[t]{2}{*}{9} & -1.238 & 0.239 & 0.812 & 0.0000007 & -0.162 & 409.98 & 0.983 & 2.25 & 0.244 \\
\hline & $(1.150)$ & (1.382) & $(6.162)$ & $(0.623)$ & $(0.678)$ & & & & \\
\hline \multirow[t]{2}{*}{10} & -0.998 & 0.165 & 0.876 & 0.000003 & -0.336 & 390.75 & 0.982 & 2.287 & 0.249 \\
\hline & $(0.706)$ & $(0.923)$ & $(6.982)$ & $(1.064)$ & $(0.961)$ & & & & \\
\hline
\end{tabular}

The per capita revenue in U.S. dollars follows nearly the exact same trend as the GDP over the course of the same years. The amount of revenue that the each Nigerian makes as compared to the GDP is and should be very similar. They rise and fall in the sample places and for the same reasons.

\section{Per Capita}

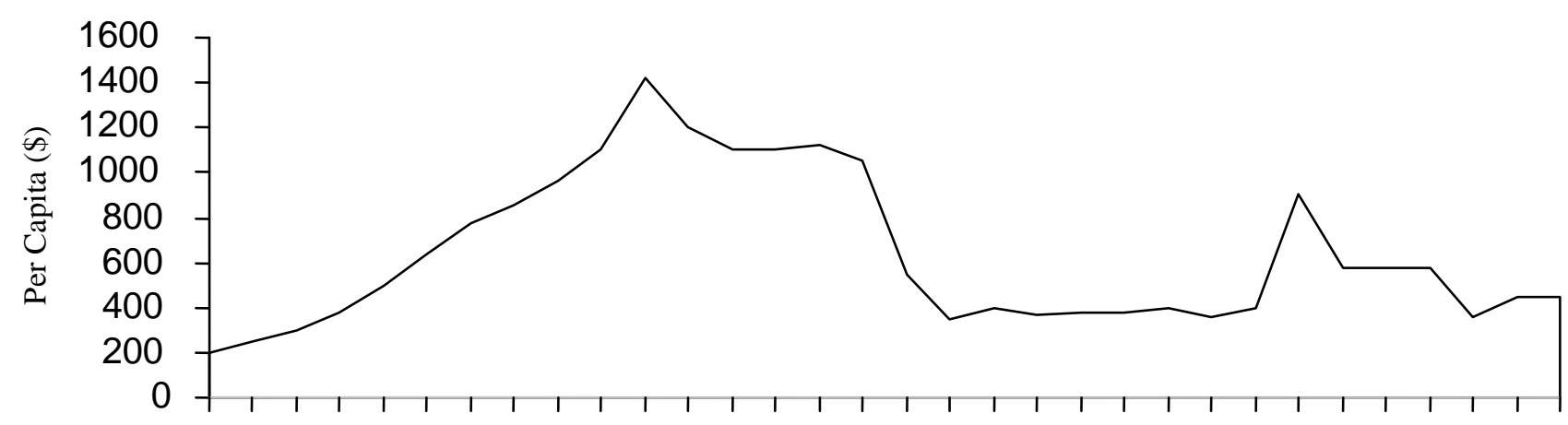

197219741976197819801982198419861988199019921994199619982000

Year 
Thous. Barrels / Day

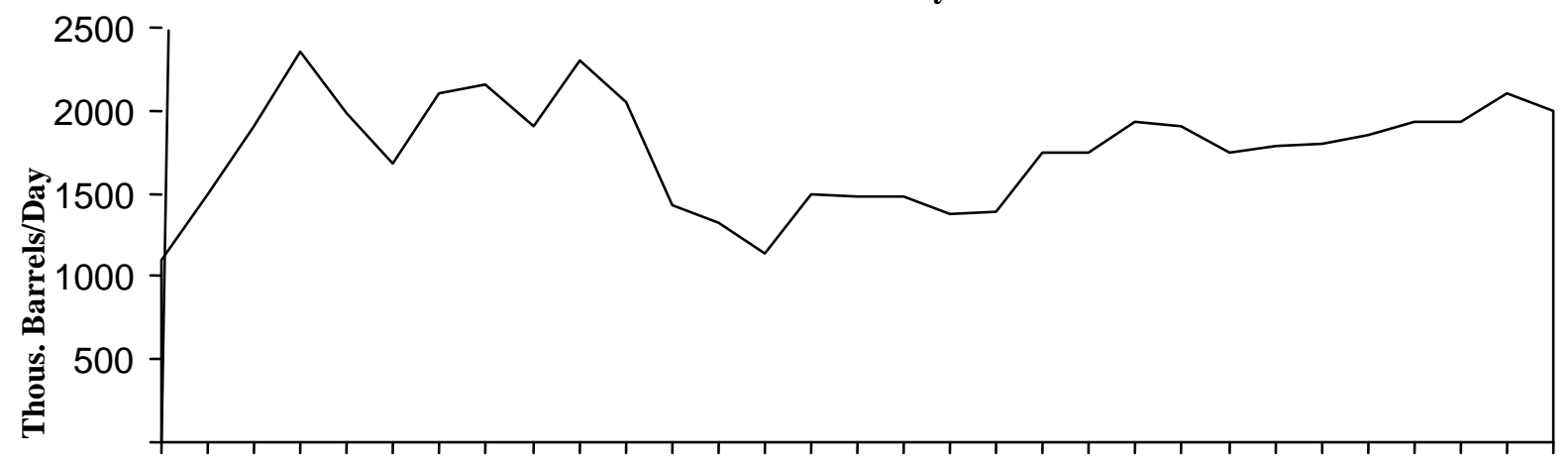

19721974197619781980198219841986198819901992199419961998

Year

The Nigerian barrels per day index over the course of the same time period also fluctuates, but not to the same degree and ways that the GDP fluctuates. In 1970 the oil began to be drilled for very openly and heavily. Over the course of the next 10 years the barrels per day rose sharply or stayed fairly constant, fluctuating naturally. During the recession and oil bust of the 1980's the barrels per day fell but were recovering by late 1987 and have continued to rise at a very steady rate since that point, peaking in 1991.

The rise came after the 1980's bust because oil multinationals and JV's became much more involved in Nigeria. The comparison of the barrels of oil per day to the trends of the GDP and the per capita are different though. The comparison between the thousands of barrels per day vs. the per capita on this next graph, show very different trends that promote reasons for investigation:

\section{Per Capita vs. Oil/Day}

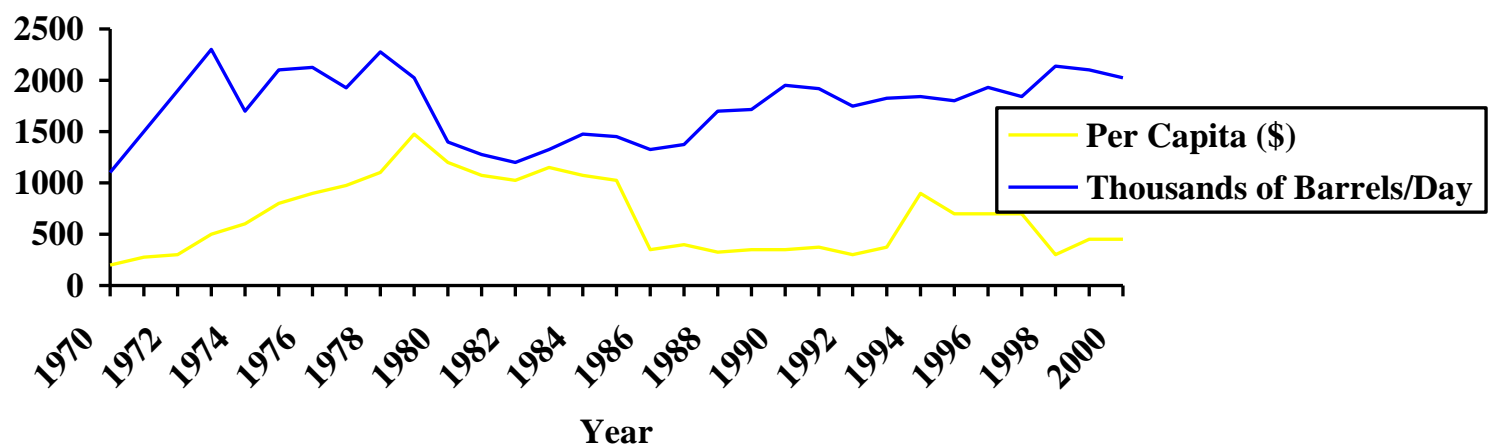

As the per capita trend follows that of the GDP exactly, it seems reasonable to believe that, with oil being backbone of the Nigerian economy, as the GDP went down, it would be largely if not entirely due to the fact that the oil revenues were failing and that barrels per day were declining. But comparing the two, one can see that this is not the case. The rates of both per capita and bbl / day both begin rising quickly and steadily in 1970. But the rate at which the oil is going up is much faster than the rate which per capita is rising. It seems legitimate to believe that as oil mining is increasing that the GDP would be increasing at a similar rate. 
The peak of the bbl / day is constant for a longer period of time also. While the per capita peaks and then almost immediately declines very sharply due to the 80 's recession, the barrels per day peaks earlier and begins to decline after the per capita begins to decline. The difference in these trends could be influenced by many reasons, but there are two main reasons. The first is that oil prices were going down as barrels per day remained constant. But an observation of oil prices shows that they were steadily increasing well into 1981.

\section{Oil Price (\$)}

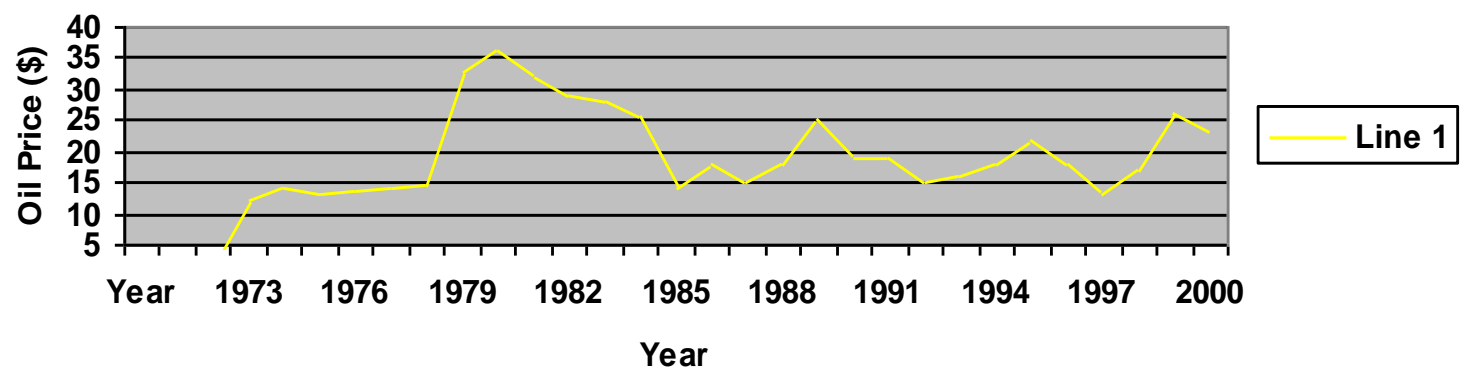

The second reason is that the money was going elsewhere. Whether it was going with the multinationals or into the pockets of corrupt politicians, the revenue from the oil was not going to the people of Nigeria. This has long been a problem with the Nigerians: revenue sharing from the profits of oil. Looking at these trends it seems valid that the per capita is not well represented by oil prices and bbl/day. Continuing the comparison of the trends bbl/day, per capita and oil prices all fell sharply remained low during the 1980's oil bust throughout the world. But in 1990 while per capita stayed at a constant low, bbl / day began a sharp increase.

Oil prices may be better suited to explain this trend difference because the oil prices remained in a trough caused by recession of the $80, \mathrm{~s}$. But it would still make sense that as oil prices remained constant, low or not, and barrels/ day increased, that the per capita would have to increase. It seems hard to argue around the idea that oil revenue was not going towards per capita. And as oil prices did in 1998 along with the barrels, per day, per capita fell sharply. The money from the oil revenue, while oil prices and production rose, was not finding its way into the economy, or into the pockets of the citizens. Thought the comparisons of these trends, a more accurate idea of how oil production and revenue affect what the people of Nigeria get out of it is achieved. And it is because the Nigerian economy does not see this money from their natural resources that they produce, the other areas of their lives are affected. Education suffers because money is not being put into schools. Infrastructure suffers because money is not being put into clean up the oil spills and the mess by mining to protect agriculture output and deforestation.

\section{Literacy Rates}

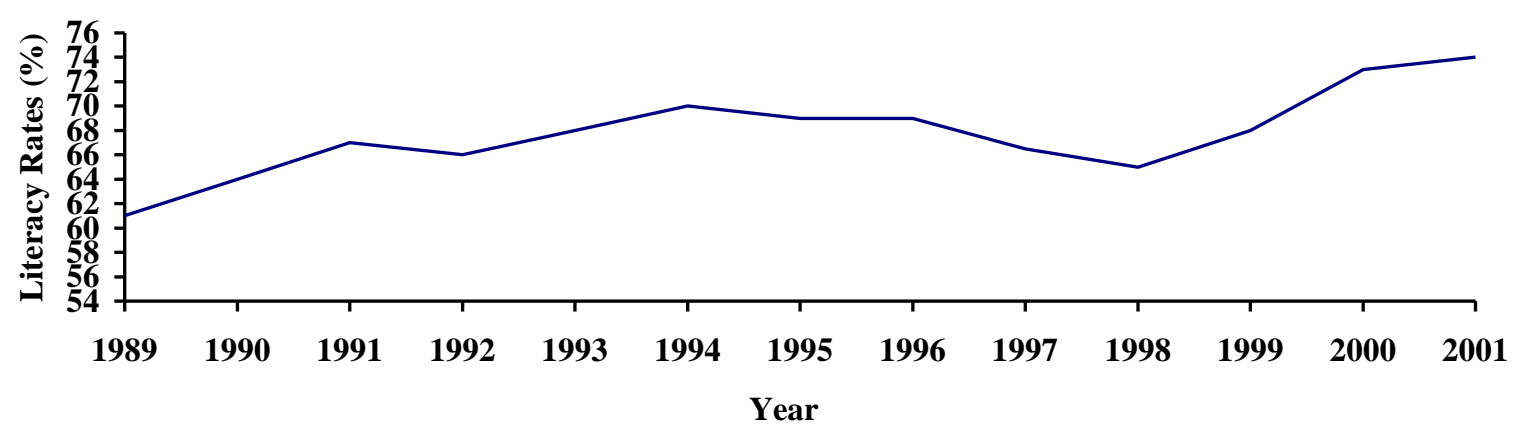


Literacy rates from 1989 to 2001 have been fluctuating and generally increasing but not the rate at which they should be. In1994 when the GDP began to rise, the literacy rate actually fall, hitting rates below those during the recession in 1998. Form 1999 to 2000 they met the $4.89 \%$ general quota but barely. The money from the GDP is not going into education as it should be. The barrels per day increase and the GDP reflects that to an ex tent but even as both of those increases the literacy rate does not. The money that should be put into education is being put else where, and it is not infrastructure.

\section{Phones/100 People}

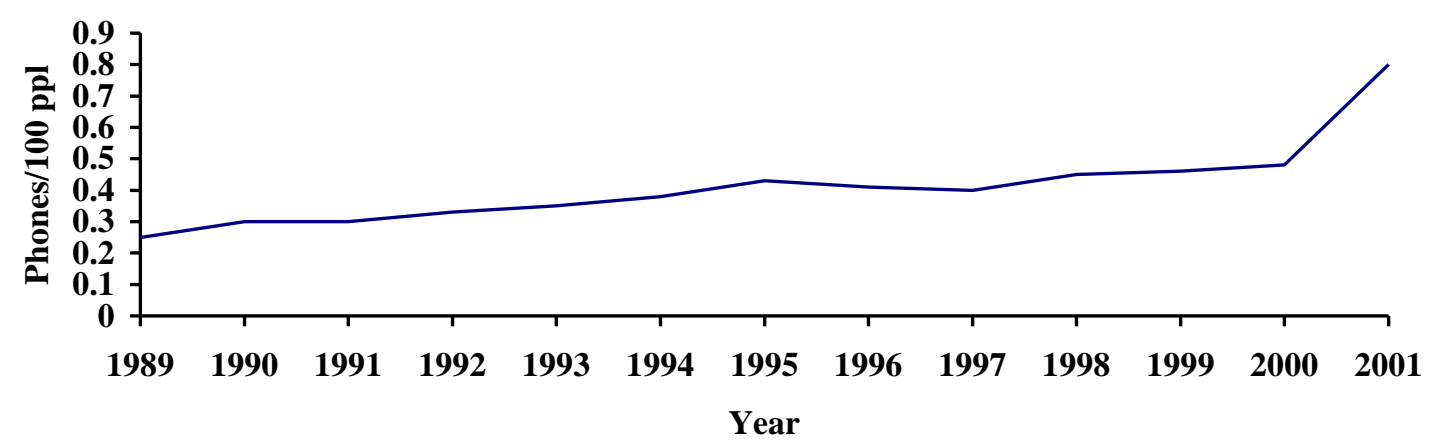

As infrastructure is developed, communications increase steadily. In a government producing 2,000,000 barrels of oil per day, the projected phone per 100 people is 7.32. Nigeria should have nearly 8 phones per person and has only nearly 1 says that money is not being put into it. As oil prices, GDP and bbl/d rise the infrastructure should too. Telephones are a good indicator of how infrastructure is doing and in Nigeria it is not doing well. Energy output in Nigeria is directly harmed by the oil business. Oil spills mess created by drilling create environment problems that failed to be addressed by the government.

Several Nigerian groups have campaigned actively, but with little success, to compel the government and major oil companies to introduce environmental safeguard. In 1988 the government created the Federal Environmental Protection Agency FEPA has had only a minor impact. In 1995 the weak and fragmented environmental movement was dealt a sharp blow when the government executed Ken Saro-Wiwa, a well-know writer who struggled to stop environmental degradation in the Niger River Delta. In many parts of the country, farmers have practiced environmental protestation for centuries.

Their techniques include planting several different crops in a single field at once to cover the ground more evenly and thereby reduce erosion and increase applying manure to farmland to maintain soil fertility; and, in certain areas such as the Jos Plateau, terracing steep slopes. And shell has been targeted as the oil multinational behind it. But despite efforts of the citizens, the lack of government funding to promote energy output has created drastic environmental problems for Nigeria. Nigeria's economy is based around oil. As poor as it may be, its economy exists because of oil. Whether it helps or hurts the country on any general ground is a value judgment but there is much information through comparison that proves the Nigerian government is definitely putting the money into the wrong places. To have an economy based so singularly on one thing, a natural resource that is prominent and prolific in the area around, it seems like Nigerian should be doing much better. The government must get organized and take control, pushing through opposition and corruption to end the inequitable apportioning of profits that is the only way that Nigeria' soil market can be harnessed to bring the country up instead of holding it down.

The grant for this project was funded by Ministry of Oil \& Gas with Research Agreement No. 20043-3ANNGP and APG Oil Inc. with Matthew Uwakonye and Gbolahan Osho for project entitled "Oil \& Gas Production and Price Stability in Nigeria". 


\section{REFERENCES}

1. Beka, F.T. and Oti, M., 1995, The distal offshore Niger Delta: frontier prospects of a mature petroleum province, in, Oti, M.N., and Postma, G., eds., Geology of Deltas: Roterdam, A.A. Balkema, p. 237-241.

2. Burke, K., 1972, Longshore drift, submarine canyons, and submarine fans in development of Niger Delta: American Association of Petroleum Geologists, v. 56 p. 1975-1983.

3. Doust, H. and Omatsola, E., 1990, Niger Delta, in Edwards J.D., and Santogrossi, P.A., eds., Divergent/passive Margin Basins, AAPG Memoir 48; Tulsa, American Association of Petroleum Geologists, p.239-248.

4. Ejedawe, J.E., 1981, Patterns of incidence of oil reserves in Niger Delta Basin: American Association of Petroleum Geologists Bulletin, v. 65, p.1574-1585.

5. Ekweozor, C.M. and Okoye, N.V., 1980, Petroleum source-bed evaluation of Tertiary Niger Delta: American Association of Petroleum Geologists Bulletin, v. 64, p. 1251-1259.

6. Evamy, B.D., Harembourne, J., Kamerling, P., Knapp, W.A., Molloy F.A., and Rowlands, P.H., 1978, Hydrocarbon habitat of Tertiary Niger Delta: American Association of Petroleum Geologists Bulletin, v. 62, p.277-298.

7. Waugh, Frederic F., Does the Consumer Benefit from Price Instability?, Quarterly Journal of Economics, Vol. 58, No. 4 (August 1944), pp. 602-614; also, Consumer Aspect of Price Instability, Econometrica, Vol. 34, No. 2, (April 1966), pp. 504-508

8. Hannesson, Rognvaldur. Energy use and GDP growth, 1950-2002." OPEC Review: Energy Economics \& Related Issues

9. Khan, Sarah Ahmad. Nigeria: The Political Economy Of Oil. Oxford: Oxford University Press, 2000

10. Owusu, Kwesi, Michael Telatin, and Simon Morley. Drops of Oil in a sea of Poverty: The Case for a new Debt in Nigeria. Jubilee Plus. September 2001: 19. 7 April 2004

11. Onayemi, Tim. Nigeria Oil: Prices, Politics, and People, Nigeriatoday.com.23. Feb. 2004

12. Suarez, Yolanda. Economy of Nigeria. 27 February 2004 


\section{NOTES}

